\title{
ANALISIS PENGUKURAN KINERJA KOPERASI SYARIAH BERDASARKAN BALANCED SCORECARD (STUDI PADA KOPERASI SYARIAH BAITURRAHMAN BANDA ACEH)
}

\author{
Hanif Syah Reza Funna*1, Suazhari ${ }^{* 2}$ \\ ${ }^{1,2}$ Program Studi Akuntansi Fakultas Ekonomi dan Bisnis Universitas Syiah Kuala \\ e-mail: hanifsyahreza090595@gmail.com ${ }^{* 1}$, suazhari@gmail.com*2
}

\begin{abstract}
This study aims to determine the performance of Baiturrahman Sharia Cooperative based on the balanced scorecard method. This research is descriptive with the method of collecting data documentation, interviews, and questionnaires. The analysis used is the Balanced Scorecard analysis. The respondents in this study were 93 cooperative members and 14 cooperative employees. Based on the results of the study using the balanced scorecard, the financial perspective obtained values in each ratio, namely the current ratio of 25, Total Debt to Total Asset Ratio of 0, and Return On Asset of 25 which showed poor performance in the cooperative financial perspective. In the customer perspective, customer retention has increased by $24 \%$, the level of customer acquisition has increased by $10 \%$, as well as the level of customer satisfaction which has a score of 4.0 which shows good customer performance. In the perspective of internal business processes, the innovation process gets a score of 4.6, the operating process gets a score of 4.7, and good after-sales service shows the performance of a good internal business process perspective. In the perspective of learning and growth, employee productivity increases, the results of employee retention indicate that the company can hold employees accountable, and employee satisfaction which scores 4.6 which shows performance in the perspective of good cooperative learning and growth. Overall, the four perspectives show good categories except in a financial perspective.
\end{abstract}

Keywords: Sharia Cooperative Performance, Balanced Scorecard, Baiturrahman Sharia Cooperative

\section{Pendahuluan}

Koperasi mempunyai peran yang penting khususnya bagi anggota dan bagi masyarakat pada umumnya, sebagaimana termaktub dalam UndangUndang Nomor 25 Tahun 1992 tentang Perkoperasian bahwa koperasi sebagai suatu oraganisasi ekonomi rakyat memiliki tujuan untuk memajukan kesejahteraan anggota pada khususnya dan masyarakat pada umumnya dan ikut membangun tatanan perekonomian nasional dalam rangka mewujudkan masyarakat yang maju, adil, dan makmur berdasarkan pancasila dan UUD 1945. Dengan melihat tujuan koperasi tersebut, maka dapat diketahui bahwa di dalam mengembangkan potensi ekonomi rakyat peran koperasi sangatlah penting.

Meskipun demikian, upaya dalam mewujudkan tujuan koperasi tersebut tidaklah mudah. Ternyata banyak koperasi di Indonesia yang belum mampu mensejahterakan anggotanya dan tidak sedikit pula yang mengalami kegagalan dan tidak aktif hingga akhirnya dibubarkan. Berdasarkan data Kementerian
Koperasi dan Usaha Kecil dan Menengah Republik Indonesia sejak tahun 2017, dari 209.000 koperasi hanya 147.000 koperasi yang aktif, sisanya sebanyak 62.000 koperasi sudah tidak aktif sehingga pemerintah melakukan pembubaran koperasi dalam rangka program reformasi total koperasi (Kompas.com, 2017). Hingga tahun 2018 jumlah koperasi yang tersisa di Indonesia berjumlah 146.290 unit yang artinya sebanyak 63.387 unit koperasi telah dibubarkan (Liputan6.com, 2018). Hal ini berarti melalui program reformasi total koperasi, pemerintah mengharapkan perkembangan koperasi di Indonesia bukan hanya dari segi kuantitas tapi lebih kepada kualitas serta daya saing koperasi.

Melihat upaya pemerintah untuk meningkatkan kualitas koperasi di Indonesia, maka hal ini menjadi tantangan yang menuntut koperasi agar mampu meningkatkan kinerjanya. Oleh karena itu dibutuhkan suatu pengukuran kinerja untuk mengevaluasi sejauh mana keberhasilan usaha koperasi. 
Metode pengukuran kinerja koperasi umumnya diukur dengan perspektif keuangan saja. Sebagaimana yang tertera dalam Peraturan Menteri Negara Koperasi dan Usaha Kecil dan Menengah Republik Indonesia Nomor 06/per/M.KUKM/V/2006 tentang Pedoman Penilaian Koperasi Berprestasi. Sedangkan perspektif non keuangan tidak termasuk dalam pengukuran kinerja koperasi. Pengukuran kinerja dengan metode ini memiliki kelemahan karena pengukuran dari perspektif keuangan saja tidak cukup untuk menggambarkan kinerja organisasi yang sesungguhnya terutama dari perspektif non keuangannya (Septiasari, Darmawan, \& Suarthana, 2015).

Dalam akuntansi manajemen dikenal suatu metode analisis kinerja yang disebut Balanced Scorecard yang dikembangkan oleh Robert S. Kaplan dan David P. Norton pada tahun 1990. Balanced scorecard merupakan salah satu metode yang dapat digunakan untuk pengukuran kinerja. Pengukuran kinerja dengan metode Balanced scorecard ini merupakan suatu ukuran yang komprehensif dalam mewujudkan kinerja yang tidak hanya mengukur perspektif keuangan saja tetapi juga perspektif non keuangan. Balance scorecard dijabarkan dalam empat perspektif yaitu, perspektif keuangan, perspektif pelanggan, perspektif proses bisnis internal, dan perspektif pembelajaran dan pertumbuhan.

Penelitian tentang penerapan balanced scorecard dalam mengukur kinerja koperasi pernah dilakukan oleh Septiasari, Darmawan, \& Suarthana (2015). Hasil dari penelitian tersebut menyatakan bahwa dibutuhkan peningkatan kinerja koperasi pada perspektif keuangan terutama pada total aset terhadap rasio hutang yang dinilai sangat tidak sehat. Namun pada ketiga perspektif lainnya dinilai cukup baik.

Penelitian lain yang terbaru yaitu oleh Silviyani, Triarso, \& Kurohman (2018). Hasil analisis penelitian tersebut menunjukkan bahwa kinerja Koperasi Unit Desa (KUD) Eko Karyo Mino di Kabupaten Jepara termasuk dalam kategori baik.

Penelitian serupa lainnya pada lembaga keuangan syariah telah diteliti oleh Reisfansyah \& Pradanawati (2017). Hasil penelitian menunjukkan kinerja BMT Syariah Ar Rahmah Kabupaten Sukoharjo masuk kategori baik secara keseluruhan meskipun pada perspektif pelanggan dinilai kurang baik.

Pada penelitian ini penulis tertarik untuk meneliti pengukuran kinerja menggunakan balanced scorecard pada Koperasi Syariah Baiturrahman yang berdomisili di Kota Banda Aceh. Penelitian ini bertujuan untuk mengetahui kinerja Koperasi Syari'ah Baiturrahman berdasarkan metode balanced scorecard.

\section{Kajian Pustaka dan Kerangka Pemikiran Kinerja dan Pengukuran Kinerja}

Schemerhorn, Hunt, \& Osborn mengartikan kinerja sebagai kualitas dan kuantitas dalam pencapaian tugas yang dilakukan oleh individu, kelompok, maupun organisasi. Kinerja merupakan hasil-hasil fungsi pekerjaan kegiatan individu atau kelompok didalam suatu organisasi yang dipengaruhi oleh faktor-faktor untuk mencapai tujuan dalam jangka waktu tertentu (Tika, 2006:121)

Berdasarkan definisi di atas dapat disimpulkan bahwa kinerja merupakan kualitas dan kuantitas dari pencapaian tugas yang dilakukan individu atau kelompok dalam suatu organisasi yang dipengaruhi beberapa faktor untuk mencapai tujuan dalam periode tertentu.

Menurut Larry D. Stout dalam Yuwono \& Sony, (2002) pengukuran kinerja merupakan proses pencatatan dan pengukuran pencapaian pelaksanaan kegiatan dalam rangka pencapaian misi (mission accomplishment) melalui berbagai hasil yang ditampilkan baik berupa produk, jasa, maupun suatu proses.

\section{Tujuan Pengukuran Kinerja}

Tujuan utama pengukuran kinerja adalah untuk memberikan motivasi bagi karyawan guna mencapai tujuan perusahaan dan mematuhi standar perilaku yang telah ditetapkan sebelumnya, agar membuahkan tindakan serta hasil yang diinginkan oleh perusahaan.

Pengukuran kinerja juga dilakukan untuk menekan perilaku yang tidak semestinya (disfunctional behaviour) serta mendorong perilaku yang semestinya diharapkan melalui umpan balik hasil kinerja pada waktunya serta imbalan (Mulyadi, 2001:416). 


\section{Manfaat Pengukuran Kinerja}

Menurut Yuwono (2002) manfaat pengukuran kinerja yang baik adalah :

a) Menelusuri kinerja terhadap harapan pelanggan sehingga akan membawa perusahaan agar lebih dekat dengan pelanggannya serta membuat seluruh personel didalam perusahaan terlibat dalam upayaupaya memberikan kepuasan terhadap pelanggan.

b) Memotivasi pegawai untuk melakukan pelayanan sebagai bagian dari mata rantai dari pelanggan dan pemasok internal.

c) Mengidentifikasi berbagai pemborosan dan sekaligus mendorong upaya-upaya untuk mengurangi pemborosan tersebut (reduction of waste).

d) Membuat tujuan strategis organisasi yang sebelumnya samar-samar menjadi semakin konkrit dari sebelumnya, sehingga didapatkan hasil pembelajaran yang lebih efisien didalam organisasi .

e) Membangun konsensus untuk melakukan suatu perubahan dengan memberikan penghargaan atas perilaku yang diharapkan.

\section{Pengukuran Kinerja Balanced Scorecard}

Balanced scorecard merupakan salah satu metode yang digunakan untuk mengukur kinerja manajemen yang ditemukan oleh Robert S. Kaplan, yang merupakan seorang profesor dari Harvard Business School dan David P. Norton dari kantor akuntan publik KPMG pada tahun 1990.

Menurut Kaplan \& Norton (2000) definisi Balanced scorecard adalah suatu sistem pengukuran yang menyeimbangkan alat ukur lama yang hanya berdimensi pada aspek keuangan dengan dimensidimensi baru yaitu pada aspek non keuangan yang terangkum dalam empat perspektif yaitu keuangan, pelanggan, proses bisnis internal, serta pembelajaran dan pertumbuhan.

\section{Tujuan Balanced Scorecard}

Tujuan dan ukuran balanced scorecard diturunkan dari visi dan strategi. Menurut Kaplan \& Norton (2000:9-13) tujuan menggunakan fokus ukuran balanced scorecard adalah untuk menghasilkan proses-proses manajemen penting, yakni menerjemahkan visi, misi serta strategi perusahaan, mengkomunikasikan dan mengaitkan berbagai tujuan dan ukuran strategis, merencanakan, menetapkan sasaran, dan menyelaraskan berbagai inisiatif strategis, meningkatkan umpan balik dan pembelajaran strategis.

\section{Manfaat Balanced Scorecard}

Kaplan \& Norton (2000:17) mengemukakan manfaat-manfaat pengukuran kinerja balanced scorecard yakni mampu menjelaskan dan mengkomunikasikan strategi ke seluruh organisasi, menyelaraskan sasaran individu dan departemen dengan strategi organisasi, menghubungkan sasaran strategis dengan target jangka panjang dan anggaran tahunan, mengidentifikasi serta menyelaraskan inisiatif strategi, melakukan pelaksanaan peninjauan strategi secara periodik, serta memperoleh umpan balik yang diperlukan untuk memperbaiki strategi.

\section{Keunggulan Balanced Scorecard}

Mulyadi (2011) mengatakan bahwa ada beberapa keunggulan utama balanced scorecard dalam mendukung proses manajemen strategis diantaranya yaitu komprehensif, koheren, seimbang, dan terukur.

\section{Perspektif Balanced Scorecard \\ Perspektif Keuangan}

Ukuran kinerja keuangan memberikan informasi sebagai dasar untuk menilai apakah strategi perusahaan, implementasi serta pelaksanaanya memberikan kontribusi pada peningkatan laba perusahaan. Oleh karenanya, laporan keuangan sebagai hasil akhir dari sebuah proses akuntansi sangatlah penting bagi pengukuran kinerja perusahaan

Kaplan \& Norton (2000) membagi tujuan perspektif keuangan ke dalam tiga tahapan siklus kehidupan bisnis yaitu bertumbuh (growth), bertahan (Sustain), menuai (Harvest). Untuk mengukur kinerja pada perspektif finansial digunakan beberapa rasio diantaranya yaitu:

a. Rasio Likuiditas

Likuiditas merupakan penilaian kemampuan bank dalam memenuhi kewajiban jangka pendeknya (Veithzal, 2013:482). Rasio Likuiditas meliputi:

1) Rasio Lancar (Current Ratio)

Rasio lancar merupakan kemampuan asset lancar perusahaan dalam memenuhi kewajiban jangka pendek dengan aset lancar 
yang dimiliki. Semakin tinggi rasio lancar semakin besar kemampuan perusahaan dalam membayar kewajiban jangka pendek, namun mengindikasikan adanya dana yang menganggur (idle cash) sehingga mengurangi profitabilitas perusahaan (Saragih, 2015).

b. Rasio Solvabilitas

Rasio solvabilitas merupakan rasio yang digunakan untuk mengukur sejauh mana aset perusahaan dibiayai dengan hutang, artinya berapa besar beban hutang yang ditanggung perusahaan dibandingkan dengan asetnya (Kasmir, 2016). Rasio solvabilitas meliputi:

1) Debt to Asset Ratio

Merupakan rasio yang digunakan untuk mengukur perbandingan antara total hutang dengan total aset. Artinya seberapa besar aset perusahaan dibiayai oleh hutang. Semakin tinggi rasio ini menunjukkan semakin besar jumlah modal pinjaman yang digunakan untuk investasi pada aset guna menghasilkan keuntungan bagi perusahaan (Syamsuddin, 2011).

c. Rasio Rentabilitas

Rasio rentabilitas merupakan kemampuan perusahaan untuk menghasilkan laba dalam periode tertentu (Munawir, 2010:33). Rasio rentabilitas terdiri dari:

1) Return On Asset

Menurut Saragih (2015) rasio ini menggambarkan seberapa efisien perusahaan dalam menggunakan aset yang dimiliki untuk menghasilkan laba selama suatu periode. Semakin besar ROA, maka semakin efisien penggunaan aset perusahaan (Saragih, 2015).

\section{Perspektif Pelanggan}

Dalam perspektif pelanggan, perusahaan melakukan identifikasi pelanggan dan segmen pasar yang akan dimasuki. Perspektif pelanggan merupakan perspektif dalam balanced scorecard yang memungkinkan perusahaan untuk menyesuaikan ukuran-ukuran pelanggan, kepuasan, loyalitas, retensi, akuisisi dan profitabilitas dengan pelanggan dan segmen pasar sasaran (Kaplan \& Norton, 2000:55).

\section{Perspektif Proses Bisnis Internal}

Perspektif proses bisnis internal memungkinkan manajer untuk mengetahui seberapa baik bisnis mereka berjalan dan apakah produk atau jasa mereka telah sesuai dengan spesifikasi pelanggan. Pada perspektif ini perusahaan melakukan pengukuran terhadap semua aktifitas yang dilakukan perusahaan untuk menciptakan suatu produk yang dapat memberikan kepuasan bagi pelanggan. Kaplan \& Norton (2000) membagi perspektif ini dalam 3 prinsip dasar yaitu:

a. Proses Inovasi

Proses inovasi terdiri atas dua komponen, yaitu: mengindentifikasi keinginan pelanggan, dan melakukan proses perancangan produk yang sesuai dengan keinginan pelanggan.

b. Proses Operasional

Proses operasional merupakan kegiatan yang dilakukan perusahaan, mulai dari saat penerimaan permintaan dari pelanggan sampai produk dikirim ke pelanggan. Proses operasi menekankan pada penyampaian produk kepada pelanggan secara efisien, dan tepat waktu.

c. Pelayanan Purna Jual

Pelayanan purna jual merupakan jasa pelayanan pada pelanggan setelah penjualan produk/jasa yang dilakukan. Adapun pelayanan purna jual yang dimaksud di sini, dapat berupa garansi, penggantian untuk produk yang rusak, dan lainlain.

\section{Perspektif Pembelajaran dan Pertumbuhan}

Tujuan dalam perspektif pembelajaran dan pertumbuhan adalah memberikan fasilitas yang memungkinkan tercapainya tujuan dalam ketiga perspektif lainnya. Kaplan \& Norton (2000) membagi tiga aspek penting untuk perspektif pembelajaran dan pertumbuhan yaitu kapabilitas pekerja, kapabilitas system informasi, motivasi, pemberdayaan dan keselarasan.

\section{Metode Penelitian \\ Desain Penelitian}

Desain penelitian merupakan pedoman peneliti dalam mengambil keputusan seberapa banyak dan kapan data harus dikumpulkan, data apa saja yang harus dikumpulkan, dari siapa peneliti memperoleh 
data, bagaimana mengumpulkannya serta bagaimana menganalisisnya (Silalahi, 2012).

\section{1) Tujuan Penelitian}

Sifat Studi penelitian ini adalah studi deskriptif. Studi deskriptif digunakan untuk mengumpulkan data yang menjelaskan karakteristik orang, situasi, atau kejadian (Sekaran \& Bougie, 2017). Penelitian ini bertujuan untuk mengeksplorasi kinerja Koperasi Syariah Baiturrahman Banda Aceh dengan menggunakan metode balanced scorecard dilakukan dengan membandingkan hasil tolak ukur pada tiap perspektif selama tiga tahun yaitu periode tahun 2015-2017.

2) Intervensi Peneliti

Tingkat intervensi merupakan tingkat keterlibatan serta pengendalian variabel yang digunakan peneliti dalam mempengaruhi penelitiannya. Tingkat intervensi dalam penelitian ini adalah intervensi minimal, yaitu studi dilakukan dalam keadaan alami dan peneliti tidak mempengaruhi data untuk mendapatkan hasil penelitian.

3) Situasi Studi

Situasi studi dalam penelitian ini dilakukan dalam pengaturan yang tidak dirancang/alami. Peneliti ingin mengetahui kinerja Koperasi Syariah Baiturrahman Banda Aceh.

4) Strategi Penelitian

Strategi dalam penelitian ini adalah studi kasus. Studi kasus berfokus pada pengumpulan informasi terkait objek tertentu, acara atau aktifitas, seperti unit atau organisasi bisnis tertentu (Sekaran \& Bougie, 2017).

5) Unit Analisis

Unit analisis merujuk pada tingkat kesatuan data yang diperlukan dalam penganalisisan data. Unit analisis dalam penelitian ini adalah tingkat organisasi, yaitu Koperasi Syariah Baiturrahman Banda Aceh.

6) Horizon Waktu

Horizon waktu yang digunakan dalam pengumpulan data adalah cross-sectional dimana data dapat dikumpulkan dalam suatu periode tertentu, dapat selama beberapa hari, minggu, bulan, atau satu tahun, untuk menjawab pertanyaan penelitian (Sekaran \& Bougie, 2017).

\section{Jenis dan Sumber Data}

Data dalam penelitian dapat dikumpulkan melalui berbagai sumber. Jenis data dalam penelitian ini terdiri dari data primer dan data sekunder.

1) Data Primer

Merupakan sumber data penelitian yang diperoleh secara langsung dari sumber asli tanpa perantara. Individu memberikan informasi ketika diwawancara, diberikan kuesioner, atau diobservasi (Sekaran \& Bougie, 2017). Data primer penelitian ini diperoleh dengan teknik kuesioner dan wawancara. Kuesioner dibagikan kepada karyawan dan nasabah Koperasi Syariah Baiturrahman, sedangkan wawancara dilakukan kepada manajer utama.

2) Data sekunder

Data sekunder merupakan data yang diperoleh dari sumber-sumber lain yang telah tersedia sebelum penelitian dilakukan (Silalahi, 2012). Data sekunder yang digunakan dalam penelitian ini adalah dokumen-dokumen yang dimiliki organisasi seperti struktur organisasi, data keuangan yang diperoleh dari laporan keuangan koperasi syariah baiturrahman periode tahun 20152017, data kepegawaian, dan data mengenai pelanggan.

\section{Teknik Pengumpulan Data}

Metode pengumpulan data dalam penelitian ini yang digunakan untuk mengumpulkan data yang digunakan adalah dokumentasi, wawancara, dan kuesioner. Dokumentasi dilakukan dengan mengumpulkan data keuangan dan data lainnya yang relevan dengan gambaran umum Koperasi Syariah Baiturrahman Banda Aceh. Wawancara dilakukan terhadap pihak terkait dengan maksud untuk melengkapi data yang diperoleh melalui dokumentasi. Pihak pihak yang dimaksud adalah manajer utama dan anggota koperasi. Kuesioner dalam penelitian ini digunakan untuk mengetahui tingkat persentase kepuasan anggota dan calon anggota serta karyawan terhadap kinerja Koperasi Syariah Baiturrahman Banda Aceh.

Penyebaran kuesioner untuk anggota dan calon anggota sebanyak 92 responden sedangkan penyebaran kuesioner untuk karyawan berjumlah 14 responden keduanya dilakukan di kantor Koperasi 
Syariah Baiturrahman Banda Aceh.Kemudian Skala likert digunakan untuk mengukur data dalam penelitian ini.

\section{Definisi Operasionalisasi Variabel Perspektif Keuangan}

Beberapa jenis analisis rasio keuangan digunakan untuk menilai kinerja finansial antara lain:

a. Analisis Likuiditas

Likuiditas menunjukkan kemampuan koperasi untuk memenuhi kewajiban jangka pendek yang harus segera dipenuhi atau kemampuan koperasi untuk memenuhi kewajiban keuangan pada saat ditagih. Analisis likuiditas ini dapat dilihat menggunakan rasio berikut:

$$
\text { Current } \text { Ratio }=\frac{\text { Aset Lancar }}{\text { Liabilitas Lancar }} \times 100 \%
$$

Current Ratio merupakan perbandingan dari total liabilitas lancar (hutang jangka pendek) dibandingkan dengan aset lancar. Berdasarkan Peraturan Menteri Negara Koperasi dan Usaha Kecil dan Menengah Republik Indonesia Nomor 06/per/M.KUKM/V/2006, current ratio yang baik adalah sebesar $175 \%$ - $<200 \%$ atau $>250 \%$ $275 \%$.

b. Analisis Solvabilitas
Solvabilitas menunjukkan kemampuan perusahaan dalam memenuhi kewajiban keuangannya apabila koperasi dilikuidasi, baik kewajiban jangka pendek maupun jangka panjan. Rasio solvabilitas dapat ditentukan dengan:

Total Debt to Total Asset Ratio $=\frac{\text { Total Liabilitas }}{\text { Total Aset }}$ X100\%

Rasio ini digunakan untuk mengukur seberapa besar persentase dana yang berasal dari hutang. Rasio ini menunjukkan sejauh mana hutang dapat ditutupi oleh aset. Berdasarkan Peraturan Menteri Negara Koperasi dan Usaha Kecil dan Menengah Republik Indonesia Nomor 06/per/M.KUKM/V/2006 tentang Pedoman Penilaian Koperasi Berprestasi, Rasio Total Debt to Total Asset yang baik adalah $\leq 40 \%$ c. Analisis Rentabilitas

Rentabilitas menunjukkan kemampuan koperasi dalam menghasilkan laba selama periode tertentu. Analisis rasio rentabilitas ini dapat ditentukan dengan:

$$
\text { Return On Assets }=\frac{\text { Sisa Hasil Usaha (SHU) }}{\text { Total Aset }} \text { X100\% }
$$

Rasio ini digunakan untuk mengukur kemampuan koperasi dalam memperoleh hasil usaha dengan memanfaatkan keseluruhan dana yang ditanamkan dalam aset untuk operasi koperasi sehingga menghasilkan keuntungan. Berdasarkan Peraturan Menteri Negara Koperasi dan Usaha Kecil dan Menengah Republik Indonesia Nomor 06/per/M.KUKM/V/2006 tentang Pedoman Penilaian Koperasi Berprestasi, Return On Asset yang baik ialah $\geq 10 \%$.

\section{Perspektif Pelanggan}

Pengukuran yang dilakukan pada perspektif pelanggan atau konsumen mencerminkan kemampuan perusahaan dalam memuaskan kebutuhan pelanggan atas jasa yang digunakan. Adapun menurut Kaplan \& Norton (2000) indikator dari perspektif pelanggan yaitu:

a. Retensi Pelanggan

Mengukur tingkat dimana perusahaan dapat mempertahankan hubungan dengan konsumen. Dapat dirumuskan sebagai berikut:

$$
\text { Retensi Pelanggan }=\frac{\text { Jumlah Pelanggan }}{\text { Jumlah Pelanggan tahun sebelumnya }} \times 100
$$

b. Akuisisi Pelanggan

Mengukur tingkat kemempuan suatu bisnis untuk menarik pelanggan baru atau memenangkan bisnis baru. Rumus yang digunakan dalam mengukur Akuisisi Pelanggan adalah:

$$
\text { Akuisisi Pelanggan }=\frac{\text { Jumlah Pelanggan Baru }}{\text { Jumlah Pelanggan }} \times 100 \%
$$

c. Kepuasan Pelanggan

Menaksir tingkat kepuasan pelanggan terkait dengan kriteria kinerja perusahaan. Tingkat kepuasan pelanggan yang semakin tinggi 
menunjukkan kualitas pelayanan oleh perusahaan yang semakin baik. Kepuasan pelanggan (anggota dan calon anggota) dapat diukur dengan menyebarkan kuesioner.

\section{Perspektif Proses Bisnis Internal}

Perspektif proses bisnis internal merupakan aktifitas untuk menghasilkan produk atau jasa bagi pelanggannya. Rangkuti (2011:102) menyatakan bahwa perspektif proses bisnis internal dapat diukur melalui indikator :

a. Inovasi

Yaitu dengan mengukur kepuasan karyawan Koperasi Syariah Baiturrahman terhadap proses inovasi. Semakin besar nilai inovasi suatu produk, maka semakin baik.

b. Operasional

Yaitu dengan mengukur kepuasan karyawan Koperasi Syariah Baiturrahman terhadap proses operasional yang sesuai dengan syariah. Semakin tinggi berarti semakin baik.

c. Layanan Purna Jual

Layanan purna jual berkaitan dengan penanganan keluhan anggota dan calon anggota, yaitu dengan mengukur jumlah keluhan yang ditangani dibandingkan dengan jumlah keseluruhan keluhan. Semakin tinggi nilai layanan purna jual menunjukkan semakin baik kemampuan perusahaan dalam menangani keluhan dari para anggota dan calon anggota.

\section{Perspektif Pembelajaran dan Pertumbuhan}

Menurut Kaplan \& Norton(2000) pengukuran yang digunakan dalam perspektif pembelajaran dan pertumbuhan adalah sebagai berikut:

a. Produktivitas Karyawan

Digunakan untuk mengetahui produktivitas karyawan dalam periode tertentu. Rumus untuk mencari tingkat produktivitas karyawan adalah:

Produktifitas Karyawan $=\frac{\text { Jumlah Pendapatan }}{\text { Jumlah Karyawan }} \times 100 \%$

b. Retensi Karyawan

Mengukur retensi karyawan adalah untuk mempertahankan selama mungkin para pekerja yang diminati perusahaan. Ukuran ini menjelaskan bahwa perusahaan membuat investasi jangka panjang dalam diri para pekerja sehingga jika ada karyawan yang berhenti bukan atas keinginan perusahaan merupakan suatu kerugian modal intelektual bagi perusahaan.

Retensi Karyawan $=\frac{\text { Jumlah Karyawan yang keluar }}{\text { Total Karyawan }} \times 100 \%$

c. Kepuasan Karyawan

Merupakan moral karyawan dan tingkat kepuasan secara keseluruhan. Semakin tinggi tingkat kepuasan karyawan berarti semakin baik, hal ini berarti karyawan merasa puas bekerja di perusahaan tempat mereka bekerja.

Kepuasan karyawan diukur dengan menyebarkan kuesioner.

\section{Teknik Pengambilan Sampel}

Banyaknya sampel yang diambil untuk perspektif pelanggan diukur dengan rumus Slovin dengan tingkat kesalahan yang diinginkan sebesar 5\% dan pengambilan sampel menggunakan teknik probability sampling dengan metode sampel acak sederhana (Simple Random Sampling). Adapun rumus Slovin sebagai berikut:

Dimana:

$$
n=\frac{N}{1+N e^{2}}
$$

$$
\begin{aligned}
& \mathrm{n}=\text { ukuran sampel } \\
& \mathrm{N}=\text { ukuran populasi } \\
& \mathrm{e}=\text { error (batas kesalahan) yang } \\
& \text { diinginkan }
\end{aligned}
$$

Sementara itu, populasi karyawan yang terdaftar pada Koperasi Syariah Baiturrahman sebanyak 14 orang, oleh karena itu menggunakan sampling jenuh, dimana seluruh populasi digunakan sebagai sampel yang berjumlah sebanyak 14 responden.

\section{Hasil dan Pembahasan Deskripsi Objek Penelitian}

Baitul Qiradh Baiturrahman didirikan pada tanggal 8 Juli 1995 dan diresmikan oleh Prof. Dr. Ing BJ Habibie dihalaman depan Mesjid Raya Baiturrahman Banda Aceh, namun secara resmi kegiatan operasional baru dimulai tanggal 2 Oktober 1995 dengan modal Rp. 16.000.000,- yang terdiri dari modal Masjid Raya Baiturrahman sebesar Rp. 
10.000.000,- dan selebihnya dari pengusaha. Kemudian pada tanggal 7 Agustus 2001 Baitul Qiradh Baiturrahman telah berbadan hukum koperasi dengan nomor: 367/BH/KDK.1.9/2001 dengan nama Koperasi Syariah Baiturrahman.

Dalam perkembangan selanjutnya Koperasi Syariah Baiturrahman mengalami perkembangan yang cukup baik pada tahun 2006. Dibuktikan dengan diresmikannya tiga kantor cabang, yaitu cabang Punge, Ulee Kareng, dan Jeulingke, Namun tahun 2008 kantor cabang Punge di merger dengan kantor Mesjid Raya, karena adanya perluasan jalan pada daerah tersebut. Tahun 2009 Koperasi Syariah Baiturrahman telah memiliki gedung sendiri yang berlokasi di Jln. Mr. Mohd. Hasan Desa Suka Damai, Batoh dan di desa Ceurih Ulee Kareng, sedangkan kantor pusat tetap berada di Komplek Masjid Raya Baiturrahman menara Utara.

\section{Karakteristik Responden}

Distribusi data karyawan terbagi atas empat kategori yaitu berdasarkan usia, jenis kelamin, latar belakang pendidikan, dan berdasarkan bidang kerja. Jika dilihat berdasarkan usia mayoritas responden terbanyak berusia antara 31-40 tahun yaitu sebanyak 9 orang responden (64,2\%). Jika dikelompokkan berdasarkan jenis kelamin maka responden perempuan berjumlah lebih banyak dibandingkan responden lakilaki yaitu sebanyak 8 orang responden $(57,1 \%)$.

Berdasarkan latar belakang pendidikan distribusi responden berada pada tingkat pendidikan antara SMA sampai dengan S1. Mayoritas pendidikan responden karyawan koperasi berlatar belakang S1 yaitu sebanyak 8 orang responden $(57,1 \%)$. Dari bidang kerja, responden terbanyak berasal dari bidang marketing yaitu sebanyak 6 responden $42,8 \%$ dari total responden karyawan Koperasi Syariah Baiturrahman.

Pada responden anggota Koperasi Syariah Baiturrahman terdiri atas tiga kategori yaitu berdasarkan usia, jenis kelamin dan jenis usaha. Apabila dilihat berdasarkan usia mayoritas responden terbanyak berusia 41-50 tahun (38\%). Berdasarkan jenis kelamin, responden berjenis kelamin laki-laki berjumlah lebih banyak dibandingkan responden perempuan yakni sebesar 60 orang responden $(65,2 \%)$. Berdasarkan jenis usaha yang terdiri dari 18 jenis usaha, mayoritas responden terbanyak adalah usaha warung kopi yaitu sebanyak 13 responden $(14,1 \%)$.

Karakteristik Responden Karyawan Koperasi Syariah Baiturrahman

\begin{tabular}{|c|c|c|c|c|}
\hline No & Karakteristik Responden & Deskripsi & Jumlah & Presentase \\
\hline \multirow[t]{5}{*}{1} & \multirow[t]{5}{*}{ Berdasarkan Usia } & 20-30 Tahun & 1 & $7,1 \%$ \\
\hline & & 31-40 Tahun & 9 & $64,2 \%$ \\
\hline & & 41-50 Tahun & 3 & $21,4 \%$ \\
\hline & & Diatas 50 Tahun & 1 & $7,1 \%$ \\
\hline & & Jumlah & 14 & $100 \%$ \\
\hline \multirow[t]{3}{*}{2} & \multirow[t]{3}{*}{ Berdasarkan Jenis Kelamin } & Laki-laki & 6 & $42,8 \%$ \\
\hline & & Perempuan & 8 & $57,1 \%$ \\
\hline & & Jumlah & 14 & $100 \%$ \\
\hline \multirow[t]{4}{*}{3} & \multirow[t]{4}{*}{ Berdasarkan Pendidikan } & SMA & 2 & $14,2 \%$ \\
\hline & & Diploma III & 4 & $28,5 \%$ \\
\hline & & Strata 1 & 8 & $57,1 \%$ \\
\hline & & Jumlah & 14 & $100 \%$ \\
\hline \multirow[t]{4}{*}{4} & \multirow[t]{4}{*}{ Berdasarkan Bidang Kerja } & Manajer Cabang & 3 & $21,4 \%$ \\
\hline & & Cs/ Teller & 5 & $35,7 \%$ \\
\hline & & Marketing & 6 & $42,8 \%$ \\
\hline & & Jumlah & 14 & $100 \%$ \\
\hline
\end{tabular}

Sumber: Data diolah (2019) 
Karakteristik Responden Anggota Koperasi Syariah Baiturrahman

\begin{tabular}{|c|c|c|c|c|}
\hline No & Karakteristik Responden & Deskripsi & Jumlah & Presentase \\
\hline \multirow[t]{5}{*}{1} & \multirow[t]{5}{*}{ Berdasarkan Usia } & 20-30 Tahun & 9 & $9,7 \%$ \\
\hline & & 31-40 Tahun & 29 & $31,5 \%$ \\
\hline & & 41-50 Tahun & 35 & $38,0 \%$ \\
\hline & & Diatas 50 Tahun & 19 & $20,6 \%$ \\
\hline & & Jumlah & 92 & $100 \%$ \\
\hline \multirow[t]{3}{*}{2} & \multirow[t]{3}{*}{ Berdasarkan Jenis Kelamin } & Laki-laki & 60 & $65,2 \%$ \\
\hline & & Perempuan & 32 & $34,7 \%$ \\
\hline & & Jumlah & 92 & $100 \%$ \\
\hline \multirow[t]{19}{*}{3} & \multirow[t]{19}{*}{ Berdasarkan Jenis Usaha } & Apotik & 1 & $1,1 \%$ \\
\hline & & Air Minum Isi Ulang & 4 & $4,3 \%$ \\
\hline & & Laundry & 4 & $4,3 \%$ \\
\hline & & Fotocopy & 5 & $5,4 \%$ \\
\hline & & Bengkel & 3 & $3,3 \%$ \\
\hline & & Jasa Menjahit (Tailor) & 4 & $4,3 \%$ \\
\hline & & Warung Kopi (Warkop) & 13 & $14,1 \%$ \\
\hline & & Jual Kue & 12 & $13,0 \%$ \\
\hline & & Jual Ikan & 8 & $8,6 \%$ \\
\hline & & Jual Bakso & 1 & $1,1 \%$ \\
\hline & & Jual Mie Aceh & 4 & $4,3 \%$ \\
\hline & & Jual Nasi Gurih/Lontong & 8 & $8,6 \%$ \\
\hline & & Rumah Makan & 3 & $3,3 \%$ \\
\hline & & Kios & 4 & $4,3 \%$ \\
\hline & & Toko Kelontong & 11 & $12 \%$ \\
\hline & & Jual Sayur \& Sembako & 3 & $3,3 \%$ \\
\hline & & Phonecell & 3 & $3,3 \%$ \\
\hline & & Jual Alat Memancing & 1 & $1,1 \%$ \\
\hline & & Jumlah & 92 & $100 \%$ \\
\hline
\end{tabular}

Sumber: Data diolah (2019)

Hasil Pengukuran Kinerja Koperasi Syariah Baiturrahman dengan Metode Balanced Scorecard Perspektif Keuangan

a. Likuiditas
Pengukuran current ratio Koperasi Syariah Baiturrahman dilakukan dengan pembagian antara aset lancar dan utang lancar. Berikut data Current Ratio pada Koperasi Syariah Baiturrahman:

Data Keuangan Current Ratio Koperasi Syariah Baiturrahman

\begin{tabular}{|c|l|l|l|}
\hline Tahun & \multicolumn{1}{|c|}{ Aset Lancar (Rp) } & \multicolumn{1}{|c|}{ Liabilitas Lancar (Rp) } & \multicolumn{1}{c|}{ Current Ratio } \\
\hline 2015 & 10.151 .575 .309 & 7.845 .233 .423 & $129 \%$ \\
\hline 2016 & 11.924 .403 .454 & 9.032 .807 .478 & $132 \%$ \\
\hline 2017 & 17.038 .043 .300 & 15.050 .975 .734 & $113 \%$ \\
\hline
\end{tabular}

Sumber: Data diolah (2019) 
Dari table diatas dapat diketahui bahwa berdasarkan Peraturan Menteri Negara Koperasi dan Usaha Kecil dan Menengah Republik Indonesia Nomor 06/per/M.KUKM/V/2006, maka current ratio dari tahun 2015 sampai dengan tahun 2017 berada dalam kriteria kurang baik pada persentase $125 \%$ - $<150 \%$ dengan nilai 25 . b. Solvabilitas

Pengukuran Total Debt to Total Asset Ratio Koperasi Syariah Baiturrahman dilakukan dengan pembagian antara total liabilitas dan total aset. Berikut data Total Debt to Total Asset Ratio pada Koperasi Syariah Baiturrahman:

Data Keuangan Total Debt to Asset Ratio Koperasi Syariah Baiturrahman

\begin{tabular}{|l|c|c|c|}
\hline Tahun & Total Liabilitas (Rp) & Total Aset (Rp) & TDAR \\
\hline 2015 & 11.089 .323 .231 & 11.916 .943 .559 & $93 \%$ \\
\hline 2016 & 12.497 .022 .181 & 13.484 .847 .611 & $93 \%$ \\
\hline 2017 & 17.455 .108 .693 & 18.705 .700 .469 & $93 \%$ \\
\hline
\end{tabular}

Sumber: Data diolah (2019)

Dari table diatas dapat diketahui bahwa berdasarkan Peraturan Menteri Negara Koperasi dan Usaha Kecil dan Menengah Republik Indonesia Nomor 06/per/M.KUKM/V/2006, maka Total Debt to Total Asset Ratio dari tahun 2015 sampai dengan tahun 2017 berada pada kriteria buruk pada persentase $>80 \%$ dengan nilai 0 . c. Rentabilitas

Pengukuran Return On Asset Koperasi Syariah Baiturrahman dilakukan dengan pembagian antara Sisa Hasil Usaha (SHU) dan total aset. Berikut data Return On Asset pada Koperasi Syariah Baiturrahman:

Data Keuangan Return On Asset Koperasi Syariah Baiturrahman

\begin{tabular}{|c|c|c|c|}
\hline Tahun & SHU $(\mathrm{Rp})$ & Total Aset $(\mathrm{Rp})$ & ROA \\
\hline 2015 & 19.733 .026 & 11.916 .943 .559 & $0,1 \%$ \\
\hline 2016 & 166.266 .620 & 13.484 .847 .611 & $1,2 \%$ \\
\hline 2017 & 162.367 .132 & 18.705 .700 .469 & $1 \%$ \\
\hline
\end{tabular}

Sumber: Data diolah (2019)

Dari table diatas dapat diketahui bahwa berdasarkan Peraturan Menteri Negara Koperasi dan Usaha Kecil dan Menengah Republik Indonesia Nomor 06/per/M.KUKM/V/2006, maka Return On Asset dari tahun 2015 sampai tahun 2017 termasuk ke dalam range 1\% - <3\% dengan kriteria kurang baik dan dengan nilai 25 . Nilai yang kecil ini menunjukkan bahwa Koperasi Syariah Baiturrahman masih kurang baik dalam menghasilkan SHU bersih.

\section{Perspektif Pelanggan}

Tolak Ukur perspektif pelanggan diantaranya adalah retensi pelanggan, akuisisi pelanggan, dan kepuasan pelanggan. a. Retensi Pelanggan

Berikut ini tabel data perhitungan retensi pelanggan Koperasi Syariah Baiturrahman:

Tingkat Retensi Pelanggan Koperasi Syariah Baiturrahman

\begin{tabular}{|c|r|r|c|}
\hline & 2 & 2 & 20 \\
& 015 & 016 & 17 \\
\hline Jumlah Pelanggan & 5 & 7 & 12 \\
& 2 & 3 & 0 \\
\hline $\begin{array}{c}\text { Jumlah Pelanggan } \\
\text { Tahun Sebelumnya }\end{array}$ & - & 5 & 73 \\
\hline $\begin{array}{c}\text { Tingkat Retensi } \\
\text { Pelanggan }\end{array}$ & - & 1 & 16 \\
\hline
\end{tabular}

Sumber: Data diolah (2019) 
Berdasarkan tabel diatas dapat dilihat bahwa retensi pelanggan Koperasi Syariah Baiturrahman mengalami peningkatan sebesar 24\%. Berdasarkan data diatas dapat dikatakan bahwa Koperasi Syariah Baiturrahman mampu mempertahankan pelanggannya dengan baik.

\section{b. Akuisisi Pelanggan}

Berikut ini tabel data perhitungan akuisisi pelanggan Koperasi Syariah Baiturrahman:

\section{Tingkat Akuisisi Pelanggan Koperasi Syariah} Baiturrahman

\begin{tabular}{|l|c|c|c|}
\hline & 2015 & 2016 & 2017 \\
\hline Jumlah Pelanggan Baru & - & 21 & 47 \\
\hline Jumlah Pelanggan & 52 & 73 & 120 \\
\hline $\begin{array}{l}\text { Tingkat Akuisisi } \\
\text { Pelanggan }\end{array}$ & - & $29 \%$ & $39 \%$ \\
\hline
\end{tabular}

Sumber: Data diolah (2019)
Dari tabel berikut dapat diketahui bahwa nilai akuisisi pelanggan Koperasi Syariah Baiturrahman pada tahun 2016 - 2017 meningkat sebesar 10\%.Peningkatan ini dikarenakan pada tahun 2016 koperasi mampu meningkatkan jumlah pelanggan sebanyak 21 orang dan di tahun 2017 jumlah pelanggan koperasi juga meningkat sebanyak 47 orang. Berdasarkan data diatas dapat dikatakan bahwa kemampuan Koperasi Syariah Baiturrahman dalam memperoleh pelanggan baru dinilai baik.

c. Kepuasan Pelanggan

Kepuasan pelanggan terhadap pelayanan Koperasi Syariah Baiturrahman secara keseluruhan responden merasa puas. Hal ini dibuktikan dengan perolehan rata-rata skor sebesar 4,0 . Berikut table kepuasan pelanggan:

Kepuasan Pelanggan Koperasi Syariah Baiturrahman

\begin{tabular}{|c|l|c|c|}
\hline No & \multicolumn{1}{|c|}{ Indikator } & Rata-rata Skor & Keterangan \\
\hline 1 & Ketanggapan Pelayanan & 4,0 & Puas \\
\hline 2 & Kecepatan dan Ketepatan Transaksi & 4,3 & Sangat Puas \\
\hline 3 & Kualitas Produk & 3,5 & Puas \\
\hline 4 & Profesionalisme & 4,2 & Puas \\
\hline \multicolumn{2}{|l|}{ Total Skor } & 4,0 & Puas \\
\hline
\end{tabular}

Sumber: Data diolah (2019)

\section{Perspektif Proses Bisnis Internal}

Pada perspektif proses bisnis internal yang menjadi tolak ukur adalah proses inovasi, proses operasional dan layanan purna jual.

a. Proses Inovasi

Indikator proses inovasi mendapatkan skor 4,6. Hal ini menunjukkan bahwa karyawan selama ini sangat puas dengan indikator proses inovasi yang dilakukan pada koperasi.

b. Proses Operasional

Proses operasional memperoleh skor rata-rata yang tinggi yaitu sebesar 4,7 yang artinya secara keseluruhan karyawan sangat puas dengan proses operasional Koperasi Syariah Baiturrahman. c. Pelayanan Purna Jual

Koperasi Syariah Baiturrahman tidak mendapatkan keluhan selama kurun waktu 3 tahun terakhir. Hal ini dikarenakan secara keseluruhan pelanggan telah puas terhadap pelayanan yang diberikan Koperasi Syariah Baiturrahman, hal ini dibuktikan dengan diperolehnya skor sebesar 4,0 pada tolak ukur kepuasan pelanggan.

\section{Perspektif Pembelajaran dan Pertumbuhan}

Pada perspektif pembelajaran dan pertumbuhan yang merupakan tolak ukur bagi perspektif pembelajaran dan partumbuhan adalah sebagai berikut:

a. Produktifitas Karyawan 
Produktifitas Karyawan Koperasi Syariah Baiturrahman

\begin{tabular}{|l|c|c|c|}
\hline \multicolumn{1}{|c|}{ Keterangan } & 2015 & 2016 & 2017 \\
\hline Perolehan SHU & 19.733 .026 & 166.266 .620 & 162.367 .132 \\
\hline Total Karyawan & 14 & 14 & 14 \\
\hline Produktifitas Karyawan & 1.409 .501 & 11.876 .187 & 11.597 .652 \\
\hline
\end{tabular}

Sumber: Data diolah (2019)

Dari table diatas dapat dilihat bahwa nilai produktifitas karyawan pada tahun 2015 mencapai 1.409.501 meningkat pada tahun 2016 mencapai 11.876.187 hal ini menunjukkan bahwa Koperasi Syariah Baiturrahman mampu meningkatkan produktifitas karyawannya. Terjadinya peningkatan yang signifikan tersebut karena adanya pelatihan-pelatihan yang dilakukan secara berkala. Pada tahun 2017 sedikit mengalami penurunan produktifitas karyawan yaitu sebesar 11.597 .652 yang menunjukkan bahwa perlu adanya peningkatan produktifitas karyawan.

b. Retensi Karyawan

\begin{tabular}{|l|c|c|c|}
\hline \multicolumn{1}{|c|}{ c. Keterangan } & 2015 & 2016 & 2017 \\
\hline Karyawan yang Keluar & 0 & 0 & 0 \\
\hline Total Karyawan & 14 & 14 & 14 \\
\hline Retensi Karyawan & $0 \%$ & $0 \%$ & $0 \%$ \\
\hline
\end{tabular}

Sumber: Data diolah (2019)

Dari tabel diatas dapat dilihat bahwa tidak terjadi peralihan karyawan dalam rentan waktu tiga tahun tersebut. Artinya koperasi mampu mempertahankan loyalitas karyawannya. Pada tabel diatas juga tidak terlihat adanya penambahan karyawan tiap tahunnya hal ini karena koperasi belum membutuhkan banyak tenaga untuk mengelola operasional koperasi.

\section{c. Kepuasan Karyawan}

Kepuasan karyawan terhadap Koperasi Syariah Baiturrahman secara keseluruhan responden merasa sangat puas. Hal ini dibuktikan dengan perolehan rata-rata skor sebesar 4,6 .Kepuasan karyawan terhadap Koperasi Syariah Baiturrahman secara keseluruhan dapat dilihat pada tabel 4.22 berikut:
Kepuasan Karyawan Koperasi Syariah Baiturrahman

\begin{tabular}{|c|l|c|l|}
\hline No & \multicolumn{1}{|c|}{ Indikator } & $\begin{array}{c}\text { Rata- } \\
\text { rata } \\
\text { Skor }\end{array}$ & Keterangan \\
\hline 1 & $\begin{array}{l}\text { Keterlibatan dalam } \\
\text { Pengambilan } \\
\text { Keputusan dan } \\
\text { Dukungan Atasan }\end{array}$ & 4,5 & Sangat Puas \\
\hline 2 & $\begin{array}{l}\text { Penghargaan Atas } \\
\text { Pekerjaan yang Baik }\end{array}$ & 4,7 & Sangat Puas \\
\hline 3 & $\begin{array}{l}\text { Akses terhadap } \\
\text { Informasi dan }\end{array}$ & 4,5 & Sangat Puas \\
\hline 4 & $\begin{array}{l}\text { Pemotivasian } \\
\text { Dorongan }\end{array}$ & 4,6 & Sangat Puas \\
\hline \multicolumn{2}{|l|}{ Total Skor Puas } \\
\hline
\end{tabular}

Sumber: Data diolah (2019)

\section{Kesimpulan, Keterbatasan dan Saran}

Berdasarkan hasil penelitian dan analisis data yang telah dijelaskan sebelumnya maka dapat diperoleh beberapa kesimpulan sebagai berikut:

1) Pada perspektif keuangan, pengukuran dari ketiga rasio menunjukkan angka yang kurang baik. Berdasarkan pengukuran yang disesuaikan dengan Peraturan Menteri Negara Koperasi dan Usaha Kecil dan Menengah Republik Indonesia Nomor 06/per/M.KUKM/V/2006, Current ratio Koperasi Syariah Baiturrahman tahun 2015 sampai dengan tahun 2017 berada dalam kriteria kurang baik pada persentase $125 \%$ - $<150 \%$ dengan nilai 25 . Total Debt to Total Asset Ratio Koperasi Syariah Baiturrahman tahun 2015 sampai dengan tahun 2017 berada dalam kriteria buruk pada persentase $>80 \%$ dengan nilai 0. Pada Return on Asset Koperasi Syariah Baiturrahman tahun 2015 sampai dengan 2017 berada pada kriteria kurang baik pada persentase $1 \%$ - <3\% dengan nilai 25 
2) Pada perspektif pelanggan, dilakukan pengukuran pada tiga ukuran yaitu retensi pelanggan yang mengalami peningkatan sebesar $24 \%$ yang berarti koperasi mampu mempertahankan pelanggan. Tingkat akuisisi pelanggan mengalami peningkatan sebesar $10 \%$ yang berarti koperasi memiliki kemampuan yang baik dalam memperoleh pelanggan baru. Serta tingkat kepuasan pelanggan memperoleh skor 4,0 yang artinya pelanggan puas dengan pelayanan Koperasi Syariah Baiturrahman.

3) Pada perspektif proses bisnis internal, hasil pengukurannya yaitu proses inovasi mendapatkan skor sebesar 4,6 yang artinya karyawan sangat puas terhadap proses inovasi produk yang senantiasa dilakukan secara berkala. Pada indikator proses operasi mendapatkan skor 4,7 yang artinya secara keseluruhan karyawan sangat puas dengan proses operasional Koperasi Syariah Baiturrahman. Pada indikator pelayanan purna jual tidak terdapat keluhan pelanggan dalam tiga tahun terakhir yang berarti pelanggan puas dengan pelayanan koperasi.

4) Pada perspektif pembelajaran dan pertumbuhan, produktifitas karyawan menunjukkan peningkatan yang signifikan pada tahun 2016 namun mengalami sedikit penurunan ditahun 2017 sehingga perlu ditingkatkan. Hasil dari retensi karyawan adalah $0 \%$ tiap tahunnya hal ini menunjukkan tidak terjadi peralihan karyawan dalam rentan waktu tiga tahun tersebut yang artinya koperasi mampu mempertahankan loyalitas karyawannya. Kepuasan karyawan koperasi memperoleh skor 4,6 yang berarti secara keseluruhan karyawan puas dengan fasilitas yang diberikan Koperasi Syariah Baiturrahman.

\section{Keterbatasan}

Penelitian ini memiliki keterbatasan yang membutuhkan perbaikan dan pengembangan dalam penelitian berikutnya. Adapun keterbatasan dalam penelitian ini adalah:

1. Hasil penelitian ini hanya sebatas penilaian awal atas penilaian kinerja dengan metode balanced scorecard pada koperasi syariah yang menjadi alternatif alat penilaian kinerja di Koperasi Syariah Baiturrahman.
2. Penelitian ini hanya meneliti salah satu koperasi syariah di Kota Banda Aceh saja yaitu Koperasi Syariah Baiturrahman. Agar dapat membandingkan kinerja Koperasi Syariah Baiturrahman dengan kinerja koperasi syariah yang lain, pada penelitian selanjutnya dapat ditambah objek penelitian di seluruh koperasi syariah di Kota Banda Aceh.

\section{Saran}

$\begin{array}{clrl}\text { Berdasarkan } & \text { hasil penelitian, } & \text { peneliti } \\ \text { memberikan saran } & \text { kepada } & \text { Koperasi } & \text { Syariah }\end{array}$ Baiturrahman:

1. Diketahui pada perspektif keuangan, pengukuran dari ketiga rasio yaitu current ratio, Total Debt to Total Asset Ratio, dan ROA menunjukkan angka yang kurang baik, sehingga diperlukan adanya upaya untuk meningkatkan current ratio mencapai angka standar dengan nilai 100 yaitu 200\% 250\%, menurunkan Total Debt to Total Asset Ratio mencapai angka standar dengan nilai 100 yakni $\leq 40 \%$, dan meningkatkan $R O A$ mencapai angka standar dengan nilai 100 yaitu $\geq 10 \%$ sesuai dengan Peraturan Menteri Negara Koperasi dan Usaha Kecil dan Menengah Republik Indonesia Nomor 06/per/M.KUKM/V/2006 tentang Pedoman Penilaian Koperasi Berprestasi.

2. Jika manajemen koperasi akan menggunakan Balanced Scorecard sebagai alat penilaian kinerja, maka sebaiknya indikator (pada komponen pernyataan) diperdalam lagi berdasarkan visi, misi dan tujuan Koperasi Syariah Baiturrahman.

3. Supaya penentuan penilaian kinerja lebih efektif dan efisien, sebaiknya ditentukan target dalam penilaian kinerja Koperasi Syariah Baiturrahman sehingga dapat diketahui ukuran keberhasilan program kerja supaya tujuan koperasi dapat tercapai dengan optimal.

\section{DAFTAR PUSTAKA}

Hamid, N. (2016). Use balanced scorecard for measuring competitive advantage of infrastructure assets of state-owned ports in Indonesia: Case in Pelindo IV, Indonesia. Journal of Management Development. https://doi.org/doi.org/10.1108/ JMD-12-20160313 
Istiqlal, C. H. (2009). Penilaian Kinerja Perbankan Syariah Dengan Metode Balanced Scorecard. La_Riba Jurnal Ekonomi Islam, III(2), 167-180.

Izzah, K., Hardyastuti, S., \& Suryantini, A. (2015). Analisis kinerja koperasi simpan pinjam Tani Makmur Kabupaten Bantul dengan metode balanced scoecard. Agro Ekonomi, 26(1), 34-48.

Kaplan, R. S., \& Norton, D. P. (2000). "Balanced Scorecard: Menerapkan Strategi Menjadi Aksi. " jakarta: Erlangga.

Kasmir. (2007). Bank dan Lembaga Keuangan Lainnya. Jakarta: PT. Raja Grafindo.

Kasmir. (2016). Analisis Laporan Keuangan. Jakarta: Raja Grafindo Persada.

Kompas.com. (2017). Pemerintah Gencar Bubarkan Koperasi yang Tidak Aktif. Retrieved from https://bisniskeuangan.kompas.com/read/2017/0 2/21/090546726/pemerintah.gencar.bubarkan.ko perasi.yang.tidak.aktif

Liputan6.com. (2018, July). Koperasi di RI sudah lebih berkualitas.

Mulyadi. (2001). Balance Scorecard: Alat Manajemen Kontemporer untuk Pelipatganda Kinerja Keuangan Perusahaan. jakarta: Salemba empat.

Mulyadi. (2011). Sistem Pengendalian Manajemen. Jakarta: Salemba empat.

Munawir, S. (2010). Analisis Laporan Keuangan. Yogyakarta: Liberty.

Proporato, M. (2017). Do hospital balanced scorecard measures reflect cause-effect relationships? International Journal of Productivity and Performance Management, $66(3 \mathrm{pp})$. https://doi.org/doi.org/10.1108/IJPPM-02-20150029

Rangkuti, F. (2011). SWOT BALANCED SCORECARD. Jakarta: PT Gramedia Pustaka Utama.

Reisfansyah, M. H., \& Pradanawati, A. (2017). Pengukuran Kinerja Perusahaan dengan Metode Balanced Scorecard Pada BMT Syariah Ar Rahmah Kabupaten Sukoharjo. Jurnal Administrasi Bisnis, 6(3).

Republik Indonesia. (n.d.). Peraturan Menteri Negara Koperasi dan Usaha Kecil dan Menengah Nomor 06/per/M.KUKM/V/2006 tentang Pedoman Penilaian Koperasi Berprestasi.

Saragih, M. (2015). Pengaruh Current Ratio Terhadap
Return On Asset Pada Perusahaan Sektor Aneka Industri Yang Listing di Bursa Efek Indonesia. Jurnal Financial, 1.

Sari, M., \& Arwinda, T. (2015). Analisis Balanced Scorecard Sebagai Alat Pengukuran Kinerja Perusahaan PT.Jamsostek Cabang Belawan. Jurnal Riset Akuntasi Dan Bisnis, 15(1), 28-42.

Schemerhorn, J. R., Hunt, J. G., \& Osborn, R. (1991). Managing Organizational Behavior. Wiley.

Sekaran, U., \& Bougie, R. (2011). Research Methods for Business, A Skill Building Approach. Jakarta: Salemba empat.

Sekaran, U., \& Bougie, R. (2017). Metode Penelitian untuk Bisnis. (A. nur Hanifah, Ed.). Jakarta: Salemba Empat.

Septiasari, M. I., Darmawan, D. P., \& Suarthana, I. W. (2015). Balanced Scorecard sebagai Pengukuran Kinerja Koperasi Perikanan Segaraning Harum Kabupaten Badung Pendahuluan. Jurnal Manajemen Agribisnis, 3(2), 110-120.

Silalahi, U. (2012). Metode Penelitian Sosial (ketiga). Bandung: PT Refika Aditama.

Silviyani, E., Triarso, I., \& Kurohman, F. (2018). Analisis Kinerja Koperasi Unit Desa Eko Karyo Mini di Kabupaten Jepara. Journal of Fisheries Resources Utilization Management and Technology, 7(1), 20-27.

Subramanyam, K. R., \& Wild, J. J. (2010). Analisis Laporan Keuangan. Jakarta Selatan: Salemba empat.

Supranto, J. (2006). Pengukuran Tingkat Kepuasan Pelanggan. Jakarta: Rineka Cipta.

Surya, L. P. L. S. (2014). Analisis Kinerja Berbasis Balanced Scorecard Pada Koperasi Xyz. EJurnal Akuntansi Universitas Udayana, 8(2), 279-293.

Syamsiah. (2014). Pemilihan Model Penentuan Kelayakan Pinjaman Anggota Koperasi Berdasarkan Algoritma Support Vector Machine , Genetic Algorithms , Dan Neural Network, 7(2), 141-153.

Syamsuddin, L. (2011). Manajemen Keuangan Perusahaan. Jakarta: PT. Raja Grafindo Persada.

Tika, M. P. (2006). Budaya Organisasi dan Peningkatan Kinerja Perusahaan. jakarta: pt bumi aksara. 
Veithzal, R. (2013). Comercial Bank Management. Jakarta: PT. Raja Grafindo Persada.

Yuwono, S. (2002). Petunjuk Praktis Penyusunan

Balanced: Menuju Organisasi yang Berfokus

Pada Strategi. Jakarta: PT Gramedia Pustaka

Utama.. 